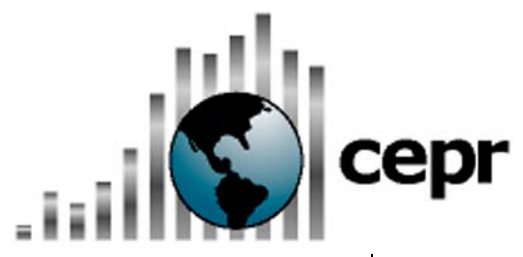

\title{
Poverty Rates in Venezuela: Getting the Numbers Right
}

\author{
BY MARK WEISBROT, LUIS SANDOVAL, AND DAVID ROSNICK
}

\section{Introduction}

Over the past year, the statement that poverty in Venezuela has increased under the government of President Hugo Chávez has appeared in scores of major newspapers, on major television and radio programs, and even journals such as Foreign Affairs ${ }^{1}$ and Foreign Policy. ${ }^{2}$ (See Appendix for a sample of such statements.) These statements have only rarely been contested or corrected.

For example, writing in the May/June 2006 issue of Foreign Affairs, Mexico's former Foreign Minister Jorge Castañeda stated that 'Venezuela's poverty figures and human development indices have deteriorated since 1999, when Chávez took office."3 A May 11, 2006 news article in the Financial Times was headlined "Chavez opts for oil-fuelled world tour while progress slows on social issues; Challengers point to failures in housing and poverty ahead of December's elections," questions whether poverty has been reduced under the Chávez administration.

Center for Economic and Policy Research 1611 Connecticut Ave, NW

Suite 400

Washington, DC 20009 tel: 202-293-5380 www.cepr.net
This paper looks at the available data on poverty in Venezuela, which show a reduction in poverty since 1999 , as well as related economic data. The paper also briefly notes how some of the mistakes surrounding the discussion of this issue have been made. Finally, we also look at the impact of the provision of health care to the poor, which has been greatly expanded over the last few years.

Mark Weisbrot is co-director, Luis Sandoval is a research assistant, and David Rosnick is a research associate at the Center for Economic and Policy Research. Dean Baker provided valuable comments, and Nihar Bhatt and Kathryn Bogel provided valuable research assistance.

${ }^{1}$ Castañeda, Jorge G., “Latin America’s Left Turn,” Foreign Affairs, May/June 2006.

2 Corrales, Javier, "Hugo Boss," Foreign Policy, January/February 2006.

${ }^{3}$ Castañeda, op cit. Although this paper does not deal with this question, it is worth noting that the UNDP Human Development Index for Venezuela has improved from 1999-2005 (from 0.765 to 0.772); and since the latest (2005) HDI is based on 2003, when the economy was in a deep recession, more recent data will show substantial improvements in the HDI for Venezuela as it becomes available.

${ }^{4}$ Webb-Vidal, Andy, "Chavez opts for oil-fuelled world tour while progress slows on social issues Challengers point to failures in housing and poverty ahead of December's elections," Financial Times, May 11, 2006. 
TABLE 1

Venezuela: Poverty Rates, 1997-2005

\begin{tabular}{|c|c|c|c|}
\hline Year & Time Period & $\begin{array}{c}\text { Households } \\
\text { Below Poverty } \\
\text { Line (\%) }\end{array}$ & $\begin{array}{c}\text { People Below } \\
\text { Poverty Line (\%) }\end{array}$ \\
\hline \multirow[t]{2}{*}{1997} & 1st half & 55.6 & 60.94 \\
\hline & 2nd half & 48.1 & 54.48 \\
\hline \multirow[t]{2}{*}{1998} & 1st half & 49.0 & 55.44 \\
\hline & 2nd half & 43.9 & 50.40 \\
\hline \multirow[t]{2}{*}{1999} & 1st half & 42.8 & 49.99 \\
\hline & 2nd half & 42.0 & 48.69 \\
\hline \multirow[t]{2}{*}{2000} & 1st half & 41.6 & 48.31 \\
\hline & 2nd half & 40.4 & 46.34 \\
\hline \multirow[t]{2}{*}{2001} & 1st half & 39.1 & 45.51 \\
\hline & 2nd half & 39.0 & 45.38 \\
\hline \multirow{2}{*}{2002} & 1st half & 41.5 & 48.13 \\
\hline & 2nd half & 48.6 & 55.36 \\
\hline \multirow[t]{2}{*}{2003} & 1st half & 54.0 & 61.00 \\
\hline & 2nd half & 55.1 & 62.09 \\
\hline \multirow[t]{2}{*}{2004} & 1st half & 53.1 & 60.15 \\
\hline & 2nd half & 47.0 & 53.90 \\
\hline \multirow[t]{2}{*}{2005} & 1st half & 42.4 & 48.80 \\
\hline & 2nd half & 37.9 & 43.70 \\
\hline
\end{tabular}

Source: Venezuela's National Statistics Institute (INE, República

Bolivariana de Venezuela)

\section{Poverty Rates: Cash Income}

Table 1 shows the percentage of Venezuelan households and people living in poverty from 1997 to 2005, at half-year intervals. The household poverty rate declined sharply from 55.6 percent in the beginning of 1997, as a result of the relatively strong growth (6.4 percent) of that year. It continued to decline, as the economy slowed to a standstill in 1998, and reached 42.8 percent in the first half of 1999, when President Chavez took office. There was some further decline in the poverty rate to 39 percent in 2001. But in 2002 poverty began to rise, surging to a peak of 55.1 percent for the second half of 2003. This was driven overwhelmingly by the oil strike (December 2002 - February 2003), which crippled the economy and caused a sharp downturn. Capital flight and political instability prior to the oil strike, including an unsuccessful military coup in April of 2002, also contributed to a severe recession that saw GDP decline by 28.1 percent from the fourth quarter of 2001 to the first quarter of $2003 .^{5}$

The economy then began to recover and grew very rapidly- 17.9 percent in 2004, and 9.3 percent in 2005. As a result of this recovery, the poverty rate dropped to 37.9 percent for the second half of 2005, the latest data available.

\footnotetext{
${ }^{5}$ This is using seasonally adjusted data for quarterly GDP (Banco Central de Venezuela, http://www.bcv.org.ve/ ).
} 
Thus if we compare the latest available data to the start of the present government, the household poverty rate fell nearly 5 percentage points - from 42.8 percent in the beginning of 1999 to 37.9 percent in the second half of 2005. The household poverty rate was thus reduced by 11.4 percent. Measuring individuals instead of households, the poverty rate decreased by 6.3 percentage points from 50 percent of the population to 43.7 percent. That was a 12.6 percent reduction in poverty. Since the economy has continued to grow rapidly this year (first quarter growth came in at 9.4 percent), the poverty rate is almost certainly significantly lower today.

How then have so many people reached a different conclusion? The most common mistake has been to use the data from the first half of 2004, which were gathered in the first quarter of that year. The household poverty rate at that time was 53.1 percent, which is of course up enormously from 1999. There are several things wrong with using this measure. Most importantly, this poverty rate is measuring the impact of the oil strike and recession of 2002-2003.

Poverty rates are very sensitive to expansion and downturns in the economy, so to compare 1999 with the first quarter of 2004, leaving off the subsequent recovery, is meaningless and misleading. As noted above, the Venezuelan economy grew by 17.9 percent in 2004 , and by 9.3 percent in 2005 . We would expect and, in fact, did see a massive reduction in poverty from an economic recovery of this magnitude. So most of the news reports and articles alleging an increase in poverty under the Chávez administration are analogous to comparing winter temperatures to spring temperatures, and concluding on that basis that there is no global warming.

Also, since a preliminary estimate of poverty rates for 2005 (38.5 percent) was released in September of that year, it is not clear why anyone would have used the out-of-date numbers. The economy had by that time already grown by more than 18 percent $^{6}$ since the first quarter 2004 numbers were collected; it should therefore have been clear that the early 2004 numbers, which reflected the prior recession, were a very serious overestimate of the poverty rate.

Some articles and reports continue to rely on this out-of-date, early 2004 data, questioning the more recent data as somehow not comparable, or as not plausible. ${ }^{7}$ For example, last week's report from the Financial Times:

"Early last year, Venezuela's National Statistics Institute said 53 per cent of the population lived in poverty at the end of 2004, 9.2 points higher than in early 1999, at the start of the Chávez government.

Irked by the numbers, the president ordered a change in INE's "methodology". Shortly after, it announced that, in mid-2005, only 39.5 per cent of people lived in poverty - a 14.5 point "improvement" in a few months."

\footnotetext{
${ }^{6}$ From the first quarter of 2004 to the third quarter of 2005, also using seasonally adjusted data (Banco Central de Venezuela, http://www.bcv.org.ve/ ).

${ }^{7}$ Michael Shifter, writing in Foreign Affairs (May-June 2006) notes the increase in poverty from 43 to 54 percent during Chávez's first four years in office, and then states that the government has "just changed its methodology for measuring poverty to reflect improvements in non-income criteria such as access to health services and education, which, it argued, were not reflected in past figures."

${ }^{8}$ Webb-Vidal, Andy, op cit.
} 
There are several mistakes here. First, as noted above and on the National Statistics Institute (INE) web site, the 53 percent figure is from the beginning of 2004, not the end; since the economy grew 17.9 percent over that year, that makes a very big difference. Second, according to the INE, there has been no change in the institute's methodology; and there is no evidence that it has changed. ${ }^{9}$ The latest figure of 39.5 percent, for the second half of 2005, still measures only cash income. ${ }^{10}$

Third, the 13.5 percent drop in the poverty rate from the beginning of 2004 to the second half of 2005 is not at all unusual given the amount of economic growth during this period. Unemployment fell from 17.1 percent in February 2004 to 10.7 percent in February of 2006. ${ }^{11}$

For example, if we look at what happened to poverty in Argentina, where a similar amount of growth took place during 2003-2005, we find a much steeper reduction in the poverty rate. During this period, the percentage of households living in poverty fell from 41.2 percent for the first half of 2003 to 22.5 for the second half of $2005 .{ }^{12}$ This is a drop of 18.7 percentage points, or a 45.4 percent reduction in the number of households living below the poverty line.

So there is no economic reason to question the decline in the poverty rate that occurred from the beginning of 2004 to the end of 2005. The amount of poverty reduction that occurred is also consistent with econometric estimates of the elasticity of poverty rates with respect to economic growth. ${ }^{13}$

\section{Non-Cash Income}

As noted above, the reduction in poverty since 1999 measures only cash income. This, however, does not really capture the changes in the living standards of the poor in Venezuela, since there have been major changes in non-cash benefits and services in the last few years. To take an analogy from the other direction, imagine that in the United States, the Medicaid and Food Stamp programs were abolished. This would have an enormous impact on the poor population of the United States, even though their cash income would have remained the same.

\footnotetext{
${ }^{9}$ Elías Eljuri, INE's President, quoted in a Miami Herald article stated that, "There is an opposition campaign against the INE...When I reported that poverty had risen [during Chavez's first four years in office], I was their hero. Now that the economy has grown and I'm reporting that poverty has dropped, I've suddenly become a liar," Andres Oppeheimer, “A miracle! Venezuela's poverty has suddenly fallen,” Miami Herald, October 27, 2005.

10 The INE also has alternative measures of poverty other than the poverty rate used here, such as the Human Development Index for Venezuela (based on the Human Development Index methodology of the UNDP), the Unsatisfied Basic Needs (UBN) method (advanced by the United Nations Economic Commission for Latin America, ECLAC), and the Social Well-being Index (Índice de Bienestar Social), all of which attempt at incorporating povertyrelated factors other than cash income.

${ }^{11}$ We are comparing February 2004 to February 2006 because the data are not seasonally adjusted. In Venezuela, as in developing countries generally, the unemployment rate does not have the same meaning as it does in high-income countries, in that many people who are severely underemployed are counted as employed. Nonetheless this change in the unemployment rate is significant.

${ }^{12}$ Instituto Nacional de Estadística y Censos (INDEC), República de Argentina. Data available online at: http://www.indec.gov.ar/.

13 See, e.g., Mejia, J. A., and R. Vos. (1997), "Poverty in Latin America and the Caribbean: An Inventory, 1980-95," Working Paper Series 1-4, Inter-American Development Bank, Washington, D.C. Available online at: http://cas.umkc.edu/econ/economics/faculty/Kostzer/Poverty-lines.pdf
} 
In Venezuela, since 2003 a series of programs have been established to provide health care for the poor, subsidized food, as well as increased access to education. For example, an estimated 14.5 million people, or 54 percent of the population, now receives free health care through the Barrio Adentro program. ${ }^{14}$ An estimated 40 to 47 percent of the population (around 10.7 to 12.5 million people) buys subsidized food through the Mercal program, at discounts averaging 41 to 44 percent. ${ }^{15}$ A May 2006 report $^{16}$ by Datanalisis, a survey research firm associated with the opposition in Venezuela, found that Mercal represented 47.3 percent share of total sales in the food distribution market in March 2006, compared to 34.7 percent in October $2005 .^{17}$

Access to free health care is a major improvement in the lives of the poor, and one that does not show up in the standard measure of poverty. It is not possible to adjust the poverty rate in a way that fully accounts for this change. For example, we could estimate the value of the health services provided free to the poor and add that to their income. However, the value of these services is so large relative to the poverty threshold that this method would move the vast majority of poor people over the poverty line.

Another way to incorporate the value of health care services to the poor is to take an estimate of what they would be spending out-of-pocket on health care if it were not provided by the government. This method vastly understates the value of these services to the poor, since in the absence of government provision many poor people simply go without needed health care, and therefore their out-of-pocket spending does not represent their actual health care needs.

Nonetheless it is worth looking at this estimate of the value of health care services to the poor. There are no recent data available specifically for Venezuela, but based on expenditure surveys of poor people in other middle-income countries, ${ }^{18}$ we can take as an estimate that the poor in Venezuela would spend about 5 percent of their income on health care.

Table 2 shows the impact of these health care benefits on poverty if we take into account the money that people below the poverty line would spend on health care in the absence of the government's provision of health care. A range of estimates is provided, based on expenditures of 4 to 6 percent of income. As can be seen, the present poverty rate would be reduced from 37.9 percent to between 36.2 and 35.3 percent; the mid-range value would be 35.8 percent.

\footnotetext{
${ }^{14}$ Rico, R. and Alva C. (2005), "Las misiones sociales venezolanas promueven la inclusión y la equidad. La revolución bolivariana sorprende al mundo," Fundación Escuela de Gerencia Social, Ediciones FEGS, Caracas.

15 “Impacto Social de la Misión Mercal,” INE, Caracas, Sept. 2005. Available online at: http://www.ine.gov.ve.

16 "Mercal es el lugar más visitado para comprar alimentos," Datanalisis, May 2006. Available online at: http://www.datanalisis.com.ve.

${ }^{17}$ In principle, the INE poverty rate should incorporate the impact of subsidized food on the poor, simply by taking into account the prices that poor people pay for food, in calculating the food basket on which the poverty line is based. The INE publishes the cost of the food basket each month, and it is not clear whether the full impact of the Mercal prices have been taken into account; if they are not, then the INE poverty rate would be overestimating the actual poverty rate.

18 See, e.g., "Determinación del gasto familiar e ingreso familiar, canasta básica de alimentos y líneas de pobreza," Dirección General de Estadística, Encuestas y Censos (DGEEC), Paraguay, July 2003; “Gastos de los hogares," INDEC, Argentina (http://www.indec.gov.ar); "Gasto de los hogares," INEGI, Mexico.
} 


\section{TABLE 2}

Venezuela: Impact of Health Care Programs on Poverty (all numbers expressed as percentages)

\begin{tabular}{|c|c|c|c|c|}
\hline & \multicolumn{2}{|c|}{2004} & \multicolumn{2}{|c|}{2005} \\
\hline & 1st half & 2nd half & 1st half & 2nd half \\
\hline Official rate & 53.1 & 47.0 & 42.4 & 37.9 \\
\hline \multicolumn{5}{|l|}{ Adjusted for health care } \\
\hline Low cost & 50.8 & 44.8 & 40.4 & 36.2 \\
\hline Medium cost & 50.3 & 44.3 & 40.0 & 35.8 \\
\hline High cost & 49.7 & 43.8 & 39.5 & 35.3 \\
\hline
\end{tabular}

Source: INE and authors' calculations

It is important to emphasize that this estimate of the impact of health care spending on the poor does not really measure the benefits that they derive from free health care. It is only estimating the money that they would otherwise spend on health care and adjusting the poverty rate accordingly. But the poor would often do without health care if it were not provided by the government, and therefore suffer from worse health, lower income, and lower life expectancy. So the value of these health care services is much greater than the amount that they would have spent out-of-pocket in the absence of the government programs.

Finally, the government has steadily increased overall social spending from 8.2 percent of GDP in 1998 to 11.2 percent of GDP in $2005^{19}$ and is expected to reach 12.5 percent of GDP in $2006 .{ }^{20}$ On education, for example, real government spending per capita has increased by 80 percent from 1998 to 2005 , with public spending on education at more than 4 percent of GDP annually during this period. Through the main literacy program, known as "Misión Robinson", an estimated 1.4 million people (or more than 5 percent of the total population) of different ages have learned how to write and read. ${ }^{21}$ These programs have also benefited the poor, again in ways that are not reflected or feasibly incorporated into the measured poverty rate.

In conclusion, there is no ambiguity as to the decline in poverty in Venezuela over the last seven years, even if we look only at cash income. Reports to the contrary, although numerous, are simply in error.

\footnotetext{
${ }^{19}$ Sistema Integrado de Indicadores Sociales para Venezuela (SISOV), http://www.sisov.mpd.gov.ve.

20 "Consolidar el crecimiento económico con menor inflación y más inversión social y productiva," Boletín Especial No. 41(2005), Ministerio de Finanzas, Venezuela.

${ }^{21}$ Rico R. and Alva C., op cit.
} 


\section{Appendix}

The following is a sample of statements appearing in major media or foreign policy journals that deny and/or misrepresent the decline in poverty that has taken place in Venezuela under the present government. This list goes back to October 2005 because a preliminary estimate of the poverty rate for 2005 (38.5 percent) was released in September of that year. Also, by that time, the economy had already grown more than 18 percent since the early 2004 numbers were collected; it should therefore have been clear that the early 2004 numbers were a serious overestimate of the current poverty rate. $^{22}$

Foreign Affairs, article by Jorge Casteñeda: “Latin America’s Left Turn,” May/June 2006

"Venezuela's poverty figures and human development indices have deteriorated since 1999, when Chávez took office.”

Financial Times, news report: "Chavez opts for oil-fuelled world tour while progress slows on social issues; Challengers point to failures in housing and poverty ahead of December's elections," May 11, 2006

"In one area - poverty - the government is adamant that it scores top marks. But there are doubts over the reliability of official data.

Early last year, Venezuela's National Statistics Institute said 53 per cent of the population lived in poverty at the end of 2004, 9.2 points higher than in early 1999, at the start of the Chavez government.

Irked by the numbers, the president ordered a change in INE's "methodology". Shortly after, it announced that, in mid-2005, only 39.5 per cent of people lived in poverty - a 14.5 point "improvement" in a few months."

Foreign Policy, article by Javier Corrales: “Hugo Boss," January 1, 2006

"Chavez has failed to improve any meaningful measure of poverty, education, or equity."

Washington Post, editorial board, editorial: “A Leader for the 21st Century,” January 18, 2006

"In Venezuela, poverty rose from 43 to 53 percent during Mr. Chavez's first six [sic] years in office."

\footnotetext{
${ }^{22}$ Long before the preliminary numbers were released (i.e. for most of 2005), it was clear that the early 2004 numbers overestimated the current poverty rate, due to the extraordinarily rapid growth of 2004 .
} 
Foreign Affairs, article by Michael Shifter: "In Search of Hugo Chávez," May/June 2006, Vol 85, Number 3

“Available data of these measures' effect are mixed and not altogether reliable. According to the Venezuelan government's National Institute of Statistics, poverty rose from 43 to 54 percent during Chávez's first four years in office . . . The government has also just changed its methodology for measuring poverty to reflect improvements in non-income criteria such as access to health services and education, which, it argued, were not reflected in past figures."

CNN “Insight,” quote from CNN host Jonathan Mann, October 17, 2005

"...More than half of Venezuela's 25 million people were found to be below the poverty line. Then the government found a new way to measure the poverty line and the numbers suddenly got better.

Changing the numbers, changing the landscape, changing things in general is what Hugo Chavez is all about."

PBS "NewsHour", quote from guest Alvaro Vargas Llosa on program: "No Resolution in Hemispheric Free Trade Talks," November 8, 2005

"When Chavez took power six years ago, about 43, 45 percent of his people were poor, and now that's about 53 percent, even though the price of a barrel of oil has gone up from about $\$ 15$ to over $\$ 60$.”

The New York Times, column by John Tierney: “The Idiots Abroad,” November 8, 2005

"The new wave of populists is led by Chavez, who's been using the recent windfall in oil revenues to expand government and solidify his hold on power. But even while $\$ 100$ million in oil money pours into Venezuela every day ( $\$ 60$ million of that from those terrible gringos north of the Rio Grande), the poverty rate has risen above 50 percent."

W ashington Post, column by Jackson Diehl: "Buying Support In Latin America," September 26, 2005

"In Chavez's Venezuela, the [poverty] rate has risen from 43 percent in 1999, the year he took office, to 53 percent last year, according to government statistics. During this same period Venezuelan oil revenue, which makes up most of the government's income, roughly doubled." 
Miami Herald, column by Andres Oppenheimer: "Responsible leftist leader set to leave office in Chile," March 9, 2006

"By comparison, oil-rich Venezuela has seen poverty grow by more than 10 percent since Chávez took office, according to official Venezuelan government figures that were recently revised after Chávez denounced them as unfair."

Miami Herald, column by Andres Oppenheimer: "Chavez having propaganda field day at U.S. expense," November 5, 2005

"If I were advising Bush, I would tell him to send some spin doctors to the press center, and expose Chavez as a sham who -- according to Venezuela's own National Institute of Statistics -- has increased poverty by 11 percent during his first five years, despite enjoying the biggest oil boom in Venezuela's history.”

Miami Herald, column by Andres Oppenheimer: "A miracle! Venezuela's poverty has suddenly fallen," October 27, 2005

"How interesting! Just a few months after Venezuela's official statistics institute reported that poverty had increased by 11 percent since President Hugo Chavez took office in 1999, the same institution is now reporting -- after a public scolding by the president -- that poverty has suddenly plummeted to pre-1999 levels. ...

My conclusion: If Venezuela's INE is right, and wants to maintain its reputation of unbiased economic reporting, it should accept some adult supervision and open its books to independent economists, like most governments do.

Otherwise, I will have to conclude that it is following Cuba's example, and has begun publishing its own happy figures, which nobody can independently corroborate. Miracles may exist, but most of us find it hard to believe in them."

Miami Herald, column by Andres Oppenheimer: "Chavez Deserves Prize for Economic Bumbling," October 9, 2005

"Chavez can claim the dubious achievement of having increased Venezuela's poverty despite the country's biggest oil boom in recent decades.

Indeed, since I disclosed in this column in March that Venezuela's official National Institute of Statistics (INE) had reported that poverty rose by 10 percent during Chavez's first five years in office, several international institutions have reported equally negative figures.

The INE, you may recall, said that poverty in Venezuela rose from 43 percent to 53 percent between 1999 and December 2004. Subsequently, Chavez lashed out against the INE, saying that it reflected the international "neoliberal" standards of measuring 
poverty, which according to him were not suitable for a "socialist" country such as Venezuela.

Others Agree

But now, other international organizations -- including the United Nations and the World Bank -- are painting a similar picture of Venezuela's social involution.

As strange as it sounds, they say poverty is rising in Venezuela despite the fact that world oil prices have soared from $\$ 8$ a barrel when Chavez took office in 1999 to about $\$ 62$ a barrel today.”

Los Angeles Times, column by contributing editor Sergio Munoz: “The Santa of the Tropics," March 5, 2006

"After seven years as president of Venezuela, Hugo Chavez's brand of populism has produced social catastrophe and economic disaster for Venezuelans, including the poor he champions.

Despite hundreds of billions of dollars in oil revenue -- $\$ 49$ billion last year alone -and social spending that includes free medical services, the country's poor are poorer, schools have not improved and the general standard of living has declined, according to a recent United Nations Human Development Report."

Associated Press Worldstream, news report by Marcel Honore: "More than 1,000 attend opposition unity rally ahead of congressional elections," October 15, 2005

"Critics accuse Chavez of becoming increasingly authoritarian and dangerously dividing this South American nation of 26 million along class lines. They say his leftleaning policies have increased poverty in the world's fifth-largest oil exporter." 